\title{
Charles Downie and the early days of palynological research at the University of Sheffield
}

\author{
WILLIAM A. S. SARJEANT \\ Department of Geological Sciences, University of Saskatchewan, \\ Saskatoon, Saskatchewan, Canada
}

\begin{abstract}
Palynological research at the University of Sheffield commenced through the initiative of Leslie R. Moore, whose principal concern was with Carboniferous spores. The discovery by Charles Downie of fossil dinoflagellates in English Jurassic strata, and his later work on Lower Palaeozoic acritarchs, resulted in an expansion of palynological research at Sheffield to all levels of the geological column, from Proterozoic to Tertiary. Recollections of the early days of palynology at Sheffield are presented in anecdotal fashion. Brief accounts of early members of the Sheffield research school are given and Downie's achievements in palynology are reviewed.
\end{abstract}

Palynological research began at the University of Sheffield through the initiative of Leslie Rowsell Moore (born 1914). Moore was born in a small town on the Somerset Coalfield, which he called "the most important coalfield in the British Isles"-an improbable claim in economic terms, but one that any geologist might consider justified, in view of the major discoveries in stratigraphy that resulted from the work of John Strachey (1671-1743) and William Smith (1769-1839) on the geology and structure of the coalfield and its environs.

Moore studied at the University of Bristol and was inspired by the teaching of Sir Arthur Trueman (18941956) to begin research on coalfield geology. He continued this work during tenure of appointments at the University of Wales, Cardiff, and the University of Glasgow. A major problem at that time was correlation of coal seams both within and between coalfields. As early as 1933, Raistrick and Simpson had suggested that fossil spores might be utilised in the making of such correlations; but, though Robert Potonié (1889-1974) had developed a non-Linnean classification of sporae dispersae and was successfully applying it in coal stratigraphy in Germany, little had been done in the British Isles to follow up Raistrick and Simpson's work. Moore was interested not merely in the spores as stratigraphical tools, but also in their morphology and relationships. His ideas on these matters, and his recognition of the value of spores in correlation, were conveyed to the Geological Society of London in a paper presented on 5 th December 1945. That paper is a landmark in the history of British palynology (Moore, 1946; see also Downie, 1977).

Moore's appointment as third Sorby Professor of Geology in the University of Sheffield (1949) not only breathed new life into a moribund Department but also permitted him to begin the creation of a research school in palynology. The earliest successful palynology student, Herbert J. Sullivan, worked on lower Coal Measure miospores. Two other early students were geologists returning to doctoral studies after army service. Leonard Gregory Love began work on fossil spores, but became more interested in the "pyritospheres" that occur in sediments and bedded iron ore deposits in many parts of the World. Roger Neves, in contrast, remained within the mainstream of palynological work on the Namurian; he is an important consultant and has guided the reseach of numerous graduate students in palynology, at first on the Dinantian and more latterly on the Mesozoic.

Charles Downie is a Glaswegian Scot, taking his batchelor's degree at the university of his home city. During Naval service, he visited almost all the island groups in the Indian Ocean save the Seychelles; a regret for him was that he had visited Aldabra without being aware that there were giant tortoises on that island and had missed seeing them. His first encounter with Leslie Moore was when the latter taught geology at the University of Glasgow; but Charles did not become concerned with Carbonliferous geology. Instead, his $\mathrm{Ph} . \mathrm{D}$. researches were on the stratigraphy of the Upper Jurassic Kimeridge Clay of Dorset. Their completion was delayed when he followed Moore to Sheffield, upon appointment as Lecturer in Geology in 1952, and became involved in class preparation; his thesis was not to be successfully presented until 1955 . The stratigraphical results of Charles' Ph.D. research were never to be published; they were submitted to the Proceedings of the Geologists' Association but were rejected by a singularly impercipient reviewer. Nevertheless, when one of my own Ph.D. students began work on the palynomorphs of the Kimmeridge Clay many years later 
(1970), Charles' draft remained the most useful account of the stratigraphy of its type outcrops.

In the climate of ideas then developing at the University of Sheffield, it was natural enough that Charles should try chemical extraction techniques on some of his samples, to see whether palynomorphs would be forthcoming. The results, I am sure, surprised him. Though spores and pollen were present, much more conspicuous and interesting elements in the assemblages that he extracted were microfossils of two other typesdinoflagellates and what were then termed "hystrichospheres".

Charles' discovery of these micro-organisms, and his account of them to the Geological Society of London on 22nd February 1956, marked another landmark in the history of British palynology. Though Late Cretaceous "hystrichospheres"-then termed "xanthidia"-had been discovered in Germany in the 1830's and briefly studied in London during the mid-nineteenth century, their study had fallen into entire neglect in England for almost a hundred years, On the Continent of Europe, their study had been resumed after an interval of over seventy years, in Germany by Walter and Otto Wetzel and Alfred Eisenack, in France principally by Georges Deflandre and in Belgium by Maria Lejeune-Carpentier. However, since those microscopists were concerned only with the morphology and probable biology of these micro-organisms, their potential in stratigraphy remained to be ascertained. Charles' paper (1957) gave a first indication that they might be of stratigraphical value in the Mesozoic.

My own entry as a student to the University of Sheffield was in 1953. After the axe of the first year examinations had trimmed away many other aspirants, I found myself part of a five-person Honours school, the other members of which were Michael P. Atherton, Bernard Knowles, John B. Richardson and Graham E. Sylvester. Two years senior to us was Herbert J. Sullivan who, after a spell of schoolteaching at Buxton Girls' High School, was to return to the University as a lecturer in Geology, his first results being published in 1962 . Later, he was to have a distinguished career in the petroleum industry in the United States and Canada.

Our first encounter with Charles Downie was as one of the leaders of a field class held in Barry, Glamorgan, South Wales-a favourite region for Professor Moore, whose first academic appointment had been at the University of Wales, Cardiff. Mr. Downie-as we then knew him-participated in the evening discourses that followed each day's excursion but remained, for us, a shadowy figure.

We came to know him soon enough, for he was given charge of the allocation of individual field mapping areas, the reports on which formed an important requirement for an Honours degree in Geology. Because I felt I knew too little about Lower Palaeozoic rocks and because I had conceived an affection for that country, I selected under his guidance a strip of terrain in Shropshire running from Leebotwood across the hill of The Lawley, the valley of the Lawley Brook, Hoar Edge and Chatwell to Church Preen. Though there were good outcrops on the ridges, the valleys were so filled with boulder clay that their solid geology was difficult to determine other than by extrapolation.

Well do I remember the occasion on which I showed my preliminary field map to Charles Downie. He sat in his chair, scrutinising it and stroking the bridge of his nose with his first finger of his right hand - a mannerism of his at that time. Then he said: "The first thing that strikes me about this map, William, is that there's no verra much on it".

I did my best to explain about the boulder clay: but he said, "I mind that there's an outcrop just here" - placing his finger in the middle of the valley of the Lawley Brook. "Go and look for it, William!"

And so I did; but three muddy days of effortful exploration about the heavily overgrown and very swampy centre of that valley convinced me that there was not, and could never have been, an outcrop. When I reported this to Charles, he looked at my map again and said: "That is the valley of the Sheinton Brook, isn't it? When I had pointed out patiently that it was not, he said: "Oh, sorry!" - and believe me, I was sorry too!

We came to know Charles better during a Second Year field excursion to the Island of Arran-an excursion during which rain fell almost continuously, so that we traversed its peaks without seeing them properly and found it hard to understand John Richardson's love for the island. Two especially wet days on the Central Igneous Complex, under the leadership of Professor Basil C. King of the University of London, stand out in my mind as among the most unpleasant field days in my experience: and we were all grateful when, through Charles' timely protests, one of them was brought to an end earlier than Professor King had intended!

During our first two years, our courses in palaeontology had been presented by Peter Colley SylvesterBradley (1913-1978), whose loud voice and dramatic delivery had enlivened lectures and field classes alike. In our Final year (1955-1956), however, Mr. SylvesterBradley was on sabbatical leave in the United States and Charles Downie took over the course. His style contrasted sharply with that of his predecessor. His delivery was lucid and well organised, his blackboard drawings much neater than the spirited scrawls of Sylvester-Bradley. Perhaps classes were a little duller, but the lecture notes one took down from SylvesterBradley had proved confusing afterwards when not illumined by the fire of his personality, whereas those one received from Charles remained clear and comprehensible.

Of we five Honours students, Graham Sylvester and 
John Richardson were the first to become interested in palynology. Graham was mapping an area of Jurassic rocks in Lincolnshire and, with Charles' encouragement, extracted palynomorphs from his samples, including an account of them into his mapping report. He had intended to continue this research for a higher degree but the attractions of matrimony, and the consequent need for a solid salary in those days when graduate students received only the most niggardly of grants, were to prove too great for him. John prepared some samples of Middle Old Red Sandstone sediments from Scotland.

The five of us graduated in June, 1956. Graham Sylvester took up an appointment with the National Coal Board; the other four of us decided to stay on and undertake research. John Richardson who, during his mapping in Arran and dissertation on the Orcadian Basin, had become very interested in the Old Red Sandstone, began work on a thesis on Devonian spores under Professor Moore's supervision. Michael began studies of metamorphic rocks and Bernard of the radioactivity of coal seams.

For my own part, I had wanted to study dinosaurs but could find neither material nor funding for this. Instead, I was given two choices; to work on Lower Carboniferous rugose corals under Professor Moore's supervision, or to study Jurassic dinoflagellates and "hystrichospheres" under Charles Downie. On the whole, I was not keen on a thesis that involved much microscope work; and I am still not clear how it came about that I chose the latter alternative. Was it Charles' persuasiveness? Was it that the word "dinoflagellate" was a beguiling echo of the word "dinosaur"? Was it simply my liking for Mesozoic rocks?

Whatever the reason, in October 1956 I found myself on field work in Yorkshire in Charles' company, collecting samples for palynological study; for I had been set the task of determining, whether dinoflagellates and "hystrichospheres" could indeed be utilised in the stratigraphical correlation of Jurassic strata. By much scrambling, we sampled remarkably high up the section of Oxford Clay exposed at High Red Cliff, Cayton Bay, though that section had been dismissed by W. J. Arkell as "scarcely accessible" (1933, p. 362). We scrambled about the Corallian rocks of Scarborough Castle Hill under lowering skies; and, progressing inland, we sought to sample the Upper Calcareous Grit at its outcrop in Howldale.

Here, there was a slight contretemps. We were perched up on the rock face when we heard a voice calling from below: "Look here, look here, what do you chaps think you're doing up there?"

We look down to see below us a large, moustached gentleman in jodhpurs and gaiters, with doublebarrelled shotgun in hand and large hound at heels, gazing up at us with face purple with fury. I said to Charles: "This is where the supervisor does his stuff!" and he descended hastily to face the empurpled landowner.

That gentleman was soon mollified. "Very well, that's fine. I thought you were quarrying chaps; I don't mind you working here if you're geological chaps." And the sampling was completed apace. A section through the Callovian and Oxfordian rocks of Dorset was taken the following Spring, during the spare time of a field trip in Dorset which Charles was leading and on which I was serving as student mapping tutor.

By then, a Palynological Research Laboratory had been opened in the Geology Department of the University of Sheffield. Here, six graduate students were soon working shoulder to shoulder, on either side of a long central table and initially using monocular petrological microscopes; indeed, all my own thesis work was done on such a microscope. One of the others working there was Raymond $\mathbf{H}$. Bate, studying Middle Jurassic ostracods under Sylvester-Bradley's supervision; and, within a year, George F. Hart had joined us, to begin work on Permian miospores under Professor Moore's supervision.

By then, Charles Downie was embarking upon two new ventures. In 1940, the Welsh geologist Herbert Price Lewis (?1895-1947) had published a brief paper on "hystrichospheres" from the Lower Palaeozoic of North Wales; but the war and his early death had prevented him from following this up. It was left to Charles to launch the study of the morphology and stratigraphical use of these microfossils in the British Palaeozoic. He presented an account of Shineton Shales assemblages to the Yorkshire Geological Society in 1958 and, after undertaking several other studies on Lower Palaeozoic microfloras, was to extend his studies to the Torridonian (Late Precambrian-lowest Palaeozoic) rocks of Scotland (Downie, 1958, 1962). An early paper on coccoliths (Downie \& Honeycombe, 1956) might have led to major discoveries on that group also, but was not followed up.

In addition, Charles became involved in two expeditions by the University of Sheffield geologists to the East African volcanic complex of Kilimanjaro. The early expeditions were led by the petrologist, structural and ore geologist William Howson Wilcockson (18911976), then in his last years as Reader in Geology at Sheffield (see Sarjeant, 1980). Later, however, Charles Downie and Peter Wilkinson were to take over and extend this work, eventually producing a definitive account of The Geology of Kilimanjaro (Downie \& Wilkinson, 1972). Since that time, Charles has made several other visits to East Africa and is by no means at the end of his studies of its geology and structure.

I was Charles' first graduate student and, for both of us, it was a matter of careful exploration toward the establishment of a working relationship. How admirably we succeeded is reflected by the fact that, not only our 
friendship, but also our collaboration in research was to continue long after I left Sheffield. This, I feel, is a particular tribute to Charles' kindness and good guidance.

During those early days, we were visited unexpectedly by an American palynologist, William R. Evitt, who was anxious to see Charles' material. He had an unconventional theory that the holes in the walls of dinoflagellates and "hystrichospheres" were performed and that the number and position of "hystrichosphere" processes was not variable, as all palynologists then thought, but regular. When he had left, Charles and I talked over his visit, shrugged our shoulders and agreed he must be a crank. Only when Evitt's results were published (1961) did we realise that he was a percipient observer who had made a major new discovery.

Another visitor was a Bristol graduate called $\mathbf{P}$. Richard Evans, who spent a few months studying dinoflagellate cysts with Charles and I before going off to embark upon what proved a distinguished palynological career in Australia. By my third year, there was a second student, David Wall, beginning the study of Lias (Lower Jurassic) microplankton assemblages that was to serve as prelude to his major studies at Woods Hole Oceanographic Institution, Massachusetts, of the encystment and ecology of living dinoflagellates. A junior technician in the Sheffield Department at that time, Barrie Dale, was to qualify himself in geology and go out to Woods Hole to work as associate with David. He has since become a major figure in this field of research and is now on the staff of the University of Oslo, Norway.

I had completed my batchelor's degree before I was 21 and had hoped to have my doctorate before I was 24 ; but the late start on microscope work rendered this impossible and I did not receive my degree until five months after my 24th birthday. John Richardson finished at about the same time and we found ourselves competing for the few available academic positions. John was initially more fortunate and secured an appointment at Kings College, London, for which we had both applied, whereas I had to spend a year in schoolteaching before gaining the appointment as Demonstrator at the University College of North Staffordshire that launched me belatedly on my academic career. During that year "in the wilderness", Charles Downie courteously continued to extend to me the facilities of the Sheffield laboratories, so that I could write up my results and commence new researches.

Both Charles and I were much concerned with the basic classification of dinoflagellate cysts. First of all, should they be treated for nomenclatural purposes as members of the animal or the plant kingdom? We plumped for the latter and expressed our reasons in a short joint note, the third author of which was a new graduate student of Charles' called Graham Williams. (Graham was beginning a thesis on the Eocene London Clay, the first of several which Charles was to supervise on the stratigraphical distribution of dinoflagellate cysts of the Tertiary rocks of southern England). When our joint paper was published (Downie, Williams \& Sarjeant, 1961), it provoked a letter of protest from Bill Evitt. This led to a long correspondence between Charles, Bill and $\mathbf{I}$, the eventual outcome of which was our joint formulation of a non-Linnean classification of the acritarchs, the former "hystrichospheres" without demonstrable dinoflagellate affinity (Downie, Evitt \& Sarjeant, 1963). This classification of acritarchs continues to be employed and is often called the D.-E.-S. classification.

Other products of joint endeavour by Charles and I have included a taxonomic review of certain spinose genera of acritarchs, now sadly outdated (Downie \& Sarjeant, 1963); a bibliography of the dinoflagellate cysts and acritarchs (Downie \& Sarjeant, 1964); a first sketch at the formulation of a descriptive terminology for them (Downie \& Sarjeant, 1966) and two attempts at a definitive familial classification (Sarjeant \& Downie, 1966, 1974). My student Roger J. Davey and Charles' student Graham Williams were to collaborate together and with us in a series of reviews of principal dinoflagellate cyst genera (Davey \& Williams, 1966a, b; Davey, Downie, Sarjeant \& Williams, 1966; Williams \& Downie, $1966 \mathrm{a}, \mathrm{b}, \mathrm{c}$ ) that have proved of such lasting significance that the volume containing them was republished in 1983 by the British Museum (Natural History). Yes, it has been a pleasant and fruitful association.

Charles' own palynological research has ranged widely. It has included the successful dating by palynological means, not only of the Manx Slates of the Isle of Man (Downie \& Ford, 1966) and the problematical Dalradian sequence of Scotland (Downie, Lister, Harris \& Fettes, 1971), but also of a primitive echinoderm whose stratigraphical origin was uncertain! (Lister \& Downie, 1967). His publications have dealt with the systematics and stratigraphical utility of acritarchs in the Late Precambrian and Lower Palaeozoic (Downie, 1959, 1960, 1963, 1974; Bruck \& Downie, 1974; Rasul \& Downie, 1974) and Devonian (Downie, 1979) and of dinoflagellate cysts in the Jurassic, Cretaceous, Tertiary and Quaternary (Ioannides, Stavrinos \& Downie, 1976; Sarjeant \& Downie, 1982; Downie, Hussain \& Williams, 1971; Costa, Downie \& Eaton, 1976; Costa, Denison \& Downie, 1978; Costa \& Downie, 1979a, b; Harland \& Downie, 1979; Bujak, Downie, Eaton \& Williams, 1980; Downie \& Singh, 1969; Reid \& Downie, 1973). He has reviewed the geological history of the microplankton (1967) and considered in detail the probable affinities of the acritarchs )1973).

After the initial phase of postgraduate research in Sheffield in the late 50's and early 60's, the succeeding years saw a great expansion in the scope of studies undertaken. Richard Lister worked on Silurian 
acritarchs, chitinozoans and spores, Tony Jenkins on Orchovician chitinozoans; however, the whole approach continued to be found and included the studies of dinoflagellate cysts from Late Triassie to Recent and acritarchs from Precambriarı to Silurian.

There can be no question that the University of Sheffield's research school in palynology has been a principal powerhouse for the development of this discipline all over the world.* As the years went by-and especially after the development of an M.Sc. course by examination in palynology-it was to attract students from many other countries, Argentina, Cyprus, Iraq, India, Pakistan, Syria, Turkey and the United States among them. In addition to those named already, other notable products of that school have included Lucy Costa, Judi Lentin, Jonathan Bujak, Geoffrey Eaton, Rex Harland, M. A. Husain, Bernard Owens, Syed Rasul, Jim Riding, Ted Spinner and John Utting.* Reunions of Sheffield graduates at meetings of the American Association of Stratigraphical Palynologists have attracted as many as 26 participants at a single session-a high number, when one remembers that these were graduates not just from a single Department but from a single discipline within that Department.

Charles has been an important figure, not merely in academic research but also in palynological consulting. He has spent two periods in Oklahoma, working with the Pan-American Petroleum Corporation (now Amoco) in Tulsa, and he has attended several scientific meetings in the United States and Canada. He has come to be regarded not only with respect but also-a rarer emotion -with affection, on both sides of the Atlantic.

Whilst it was Leslie Moore who laid the foundations on palynological research at Sheffield, the developing structure has been shaped to an almost equal degree by Charles Downie, before and after he succeeded Moore as Sorby Professor. Not just myself alone but palynologists in general, whether in universities, geological surveys or the petroleum industry, owe to Charles a great debt. I cannot believe he is retiring; I am sure that he is merely moving into another sphere of activity; but, whatever his future plans are, I am confident that they will be carried out admirably.

* See also the appendix at the end of this volume.

\section{REFERENCES}

Arkell, W.J. 1933. The Jurassic System in Great Britain. 681 pp., frontis +41 pls., 97 figs. Clarendon Press Oxford.

Bruck, P.M. \& Downie, C. 1974. Silurian microfossils from west of the Leinster Granite. J. geol. Soc. Lond., 130, 383 386, fig. 1.

Bujak, J.P., Downie, C, Eaton, G.L. \& Williams, G.L. 1980. Dinoflagellate cysts and acritarchs from the Eocene of southern England. Palaeont. Assoc. Spec. Paps., London, no. 24, 104 pp., 22 pls., 24 text-figs.

Costa, L., Denison, C. \& Downie, C. 1978. The Paleocene/
Eocene boundary in the Anglo-Paris basin. J. geol. Soc. Lond., 135, 261-264, figs. 1-2.

Costa, L.I., \& Downie, C. 1979a. Cenozoic dinocyst stratigraphy of sites 403 to 406 (Rockall Plateau), IPOD, Leg 48. In: Montadert, L. \& Roberts, D.G. (Eds.), Init Rep ts Deep Sea Drilling Project, 48, 513-522, fig. 1, tabs. 1-5.

Costa, L. and Downie, C. 1979b. The Wetzeliellaceae; Palaeogene dinoflagellates. Proc. IV Int. Palynol. Conf., Lucknow, 2, 34-46, text-figs. 1-3.

Costa, L.I, Downie, C. \& Eaton, G.L. 1976. Palynostratigraphy of some Middle Eocene sections from the Hampshire Basin (England). Proc. Geol. Ass., London, 87(3), 273-284, text-figs. 1-3.

Davey, R.J., Downie, C., Sarjeant, W.A.S. \& Williams, G.L. 1966. Fossil dinoflagellate cysts attributed to Baltisphaeridium. In: Davey, R.J., Downie, C., Sarjeant, W.A.S. \& Williams, G.L., Studies on Mesozoic and Cainozoic dinoflagellate cysts. Bull. Br. Mus, nat. Hist., London, (Geol.), Suppl. 3, 157-173, pls. 2, 3, 8, 9, 11, text-figs. 41-45.

Davey, R.J. \& Williams, G.L. 1966a The genera Hystrichosphaere and Achomosphaera. In: Davey, R.J., Downie, C., Sarjeant, W.A.S. \& Williams, G.L., Studies on Mesozoic and Cainozoic dinoflagellate cysts. Bull. Br. Mus. nat. Hist., London, (Geol.), Suppl. 3, 28-52, pls. 1-5, 9, text-figs. 812 , table 2 .

Davey, R.J. \& Williams, G.L. 1966b. The genus Hystrichosphaeridium and its allies. In: Davey, R.J., Sarjeant, W.A.S. \& Williams, G.L., Studies on Mesozoic and Cainozoic dinoflagellate cysts. Bull. Br. Mus. nat. Hist., London, (Geol.), Suppl. 3, 53-106, pls. 3, 9, 10, 11, 12, text-figs. 1322 , table 3.

Downie, C. 1957. Microplankton from the Kimeridge Clay. $Q$. Jl. geol. Soc. Lond., 112, 413-34, pl. 20, text-figs. 1-6.

Downie, C. 1958. An assemblage of microplankton from the Shineton Shales (Tremadocian). Proc. Yorks. geol. Soc., 31(4), no. 12, 331-349, pl. 16-17, text-figs. 1-5, tab. 1.

Downie, C. 1959. Hystrichospheres from the Silurian Wenlock Shales of England. Palaeontology, London, 2(1), 56-71, pls. 1-3.

Downie, C. 1960.Deunffia and Domasia, new genera of hystrichospheres. Micropaleontology, New York, 6(2), 197-202, pl. 1 , text-figs. 1-5.

Downie, C. 1962. So-called spores from the Torridonian: Report of Demonstration. Proc. geol. Soc. Lond., no. 1600, 127-128.

Downie, C. 1962. 'Hystrichospheres' (acritarchs) and spores of the Wenlock Shales (Silurian) of Wenlock, England. Palaeontology, London, 6(4), 625-652, pls. 91-92, text-figs. 1-4, tabs. 1-15.

Downie, C. 1967. The geological history of the microplankton. Rev. Palaeobot. Palyn. 1(1), 269-281, text-figs. 1-3, tab. 1.

Downie, C. 1973. Observations on the nature of the acritarchs. Palaeontology, London, 16(2), 239-259, pls. 1-4, text-fig. 1.

Downie, C. 1974. Acritarchs from near the PrecambrianCambrian boundary - a preliminary account. Rev. Palaeobot. Palynol. 18, 57-60, text-figs. 1-2.

Downie, C. 1977. Professor L.R. Moore. Univ. Sheffield Gazette, 57, 32-33, port.

Downie, C. 1979. Devonian acritarchs. Palaeontology Spec. Paps., no. 23, 185-188, text-figs. 1-2.

Downie, C., Booth, G., Rasul, S.M. \& Potter, T. 1979. Changes in the acritarch assemblages at the Tremadoc boundaries in the United Kingdom. Proc. IV Int. Palynol. Conf., Lucknow, 2, 78-83, text-figs. 1-3, tab. 1. 
Downie, C., Evitt, W.R. \& Sarjeant, W.A.S. 1963. Dinoflagellates, hystrichospheres and the classification of the acritarchs. Stanf. Univ. Publs: Geological Sciences, 7(3), 1-16.

Downie, C. \& Ford, T.D. 1966. Microfossils from the Manx Slate Series.Proc. Yorks. geol. Soc., 35(3), no. 13, 307-322, pls. 17-18, text-figs. 1-2, tab. 1.

Downie, C. \& Honeycombe, R.K. 1956. Examination of fossil coccoliths in the electron microscope. Nature, 117, 947-948, text-figs. 1-2.

Downie, C., Hussain, M.A. \& Williams, G.L. 1971. Dinoflagellate cyst and acritarch associations in the Paleogene of southeast England. Geosci. Man, 3, 29-35, pls. 1-2, text-figs. 1-6.

Downie, C., Lister, T.R., Harris, A.L. \& Fettes, D.I. 1971. A palynological investigation of the Dalradian rocks of Scotland. Nat. Envir. Res. Coun. Inst. geol. Sci. Rep., No. 71/9, 1-29, pls. 1-3, fig. 1, tabs. 1-3.

Downie, C. \& Sarjeant, W.A.S. 1963. On the interpretation and status of some hystrichosphere genera. Palaeontology, London, 6(1), 83-96.

Downie, C. \& Sarjeant, W.A.S., 1964. Bibliography and index of fossil Dinoflagellates and Acritarchs. Mem. geol. Soc. Am., 94, 180 pp., 3 graphs.

Downie, C. \& Sargeant, W.A.S., 1966. The morphology, terminology and classification of fossil dinoflagellate cysts. In Davey, R.J., Downie, C., Sarjeant, W.A.S. \& Williams, G.L., Studies on Mesozoic and Cainozoic dinoflagellate cysts. Bull. Br. Mus. nat. Hist., London, (Geol.), Suppl. 3, 10-17, text-figs. 1-4.

Downie, C. \& Singh, G. 1969. Dinoflagellate cysts from estuarine and raised beach deposits at Woodgrange, Co. Down, N. Ireland. Grana palynol. 9(1-3), 124-132, text-figs. $1-12$, tab. 1.

Downie, C. \& Wilkinson, P. The Geology of Kilimanjaro. 273 pp., 10 pls., 44 figs., 28 tabs., 1 map incl. Univ. Sheffield, Dept. Geology.

Downie, C., Williams, G.L. \& Sarjeant, W.A.S. 1961. Classification of fossil microplankton. Nature, 192(4801), 471.

Evitt, W.R., 1961. Observations on the morphology of fossil dinoflagellates. Micropaleontology, London, 7(4), 385-420, pis. 1-9, text-figs. 1-8.

Harland, R. \& Downie, C. 1969. The dinoflagellates of the interglacial deposits at Kirmington, Lincolnshire. Proc. Yorks. geol. Soc., 37(2), no. 11, 231-237, pl. 7.

Ioannides, N.S., Stavrinos, G.N. \& Downie, C. 1976. Kimmeridgian microplankton from Clavell's Hard, Dorset, England. Micropleontology, New York, 22(4), 443-478, pls. 1-5, text-figs. 1-14.

Lewis, H.P. 1940. The microfossils of the Upper Caradocian phosphate deposits of Montgomeryshire, North Wales. Ann. Mag. Nat. Hist. ser. II, 5, 1-39, pls. 1-4, text-figs. 1-3.
Lister, T.R. \& Downie, C. 1967. New evidence for the age of the primitive echinoid Myriastiches gigas. Palaeontology, London, 10(2), 171-174, pl. 23.

Moore, L.R. 1946. On the spores of some Carboniferous plants; their development. $Q$.J1 geol. Soc. Lond., 102, 251 298, pls. 16-18, figs. 1-12.

Rasul, S.M. \& Downie, C. 1974. The stratigraphic distribution of Tremadoc acritarchs in the Shineton Shales succession, Shropshire, England. Rev. Palaeobot. Palyn., 18, 1-9, tabs. 1-3.

Reid, P.C. \& Downie, C. 1973. The age of the Bridlington Crag. Proc. Yorks. geol. Soc., 39(3), no. 15, 315-318, tabs. 1-2.

Sarjeant, W.A.S. \& Downie, C. 1966. The classification of dinoflagellate cysts above generic level. Grana Palyn., 6(3), 503-527

Sarjeant, W.A.S. \& Downie, C. 1974. The classification of dinoflagellate cysts above generic level: a discussion and revisions. In: Sah, S.C.D. \& Cross, A.T. (Eds.). Symposium on Stratigraphical Palynology, Birbal Sahni Institute of Palaeobotany, Spec. Publ. no. 3, 9-32.

Sarjeant, W.A.S. \& Downie, C. 1982. The Upper Cretaceous dinoflagellate cyst Raphidodinium Deflandre: A Restudy. Grana, 21, 115-120, figs. 1-4.

Sullivan, H.J. 1962. Distribution of miospores through coals and shales of the coal measures sequence exposed in Wernddu Claypit, Caerphilly (South Wales). Q. JI geol. Soc. Lond., 118(3), 353-373, pl. 15, fig. 1, tab. 1.

Williams, G.L. \& Downie, C. 1966. The genus Hystrichokolpoma. In: Davey, R.J., Downie, C., Sarjeant, W.A.S. \& Williams, G.L., Studies on Mesozoic and Cainozoic dinoflagellate cysts. Bull. Br. Mus. nat. Hist., London, (Geol,), Suppl. 3, 176-181, pl. 17, text-figs. 4-6.

Williams, G.L. \& Downie, C. 1966. Wetzeliella from the London Clay. In: Davey, R.J., Downie, C., Sarjeant, W.A.S. \& Williams, G.L., Studies on Mesozoic and Cainozoic dinoflagellate cysts. Bull. Br. Mus. nat. Hist., London, (Geol.), Suppl. 3, 182-198, pls. 18-20, text-figs. 47-50.

Williams, G.L. \& Downie, C. 1966. Further dinoflagellate cysts from the London Clay. In: Davey, R.J., Downie, C., Sarjeant, W.A.S. \& Williams, G.L., Studies on Mesozoic and Cainozoic dinoflagellate cysts. Bull. Br. Mus. nat. Hist., London, (Geol.), Suppl. 3, 215-235, pls. 24-26, text-figs. $56-64$. 